\title{
PERSEPSI MASYARAKAT TENTANG ALTERNATIF PEMECAHAN MASALAH TRANSPORTASI DI JALAN RIAU KOTA PEKANBARU
}

\author{
M. Taufik Nizam ${ }^{1}$, Puji Astuti ${ }^{2}$, Mardianto Manan $^{3}$ \\ ${ }^{1,2,3)}$ Program Studi Perencanaan Wilayah dan Kota, Fakultas Teknik \\ Universitas Islam Riau \\ Jl. Kaharuddin Nasution No.113, Pekanbaru \\ email: pujiastutiafrinal@yahoo.co.id,manardianto1969@yahoo.com
}

\begin{abstract}
Riau street in Pekanbaru classified as secondary arterial roads with solid activit s so susceptible to the problem of traffic. The physical condition of damaged roads, land use mix and irregular, activities of right and left side crowded streets, parking inadequate, lack of public transport, and the behavior of road users who are not orderly, is the picture of the problem of traffic that occurs on the Riau street. This is supported also by the growth in the number of private vehicles. The accumulation of a variety of symptoms that led to the road capacity can no longer accommodate the volume of passing vehicles, causing traffic delays. One way to unravel this problem is to assess the public's perception of road users alternative solutions to problems related to urban transport in Riau street. The method used is descriptive quantitative with the number of respondents 100 people and supported by a statement from the policy holder of the traffic in the city of Pekanbaru. Public perception related factors causing transportation problems in Riau street is the traffic policy is less strict in discipline of road users, the traffic volume exceeds the capacity of the road, setting traffic light rigid, road users are not orderly, parking space is limited, public transport is limited, and the illegal parking. Alternative solutions is the increase in traffic policy, modify or regulate the flow of traffic, optimization of public transport facilities and infrastructure, restrictions on the use of private vehicles, road widening, traffic lights adjustment, socialization regulation and enforcement, and the construction of flyovers.
\end{abstract}

Keywords : Public's Perseption, Transportation, Urban, Alternative

\begin{abstract}
Abstrak: Jalan Riau di Kota Pekanbaru tergolong jalan arteri sekunder dengan aktifitas yang padat sehingga rentan terjadi permasalahan lalu lintas. Kondisi fisik jalan yang rusak, guna lahan campuran dan tidak teratur, kegiatan samping kanan-kiri jalan yang padat, perparkiran yang tidak memadai, minimnya sarana angkutan umum, dan tingkah laku pengguna jalan yang tidak tertib, adalah gambaran permasalahan lalu lintas yang terjadi di Jalan Riau. Hal tersebut didukung juga oleh pertumbuhan jumlah kendaraan pribadi. Akumulasi dari berbagai gejala tersebut menyebabkan kapasitas jalan tidak dapat lagi menampung volume kendaraan yang lewat sehingga terjadi tundaan lalu lintas. Salah satu jalan untuk mengurai permasalahan tersebut adalah dengan menilai persepsi masyarakat pengguna jalan terkait alternatif pemecahan masalah transportasi perkotaan di Jalan Riau. Metode penelitian yang digunakan adalah deskriptif kuantitatif dengan jumlah responden 100 orang serta didukung oleh keterangan dari pemegang kebijakan lalu lintas yang ada di Kota Pekanbaru. Persepsi masyarakat terkait faktor penyebab permasalahan transportasi di Jalan Riau adalah kebijakan lalu lintas kurang tegas dalam menertibkan pengguna jalan, volume kendaraan melebihi kapasitas jalan, pengaturan traffic light yang kaku, pengguna jalan tidak tertib, lahan parkir terbatas, angkutan umum terbatas, dan petugas parkir liar. Sedangkan untuk alternative pemecahannya adalah peningkatan kebijakan lalu lintas, mengubah atau mengatur arus lalu lintas, pengoptimalan sarana dan prasarana angkutan umum, pembatasan penggunaan kendaraan pribadi, pelebaran jalan, penyesuaian lampu lalu lintas, sosialisasi peraturan dan penegakan hukum, dan pembangunan fly over.
\end{abstract}

Kata kunci : Persepsi Masyarakat, Transportasi, Perkotaan, Alternatif 
Kota-kota besar di Indonesia berkembang dengan pesat. Pertumbuhan penduduk cukup tinggi, serta peningkatan perekonomian masyarakat menuntut laju pembangunan yang tinggi, sehingga menimbulkan peningkatan mobilitas yang tinggi pula dari pelaku pembangunan di kotakota besar tersebut. Untuk memenuhi segala pergerakan aktivitas penduduknya perlu didukung dengan penyediaan fasilitas transportasi yang memadai.

Usaha pemerintah baik pusat maupun daerah untuk memecahkan masalah transportasi perkotaan telah banyak dilakukan, baik dengan meningkatkan kapasitas jaringan jalan yang ada maupun dengan pembangunan jaringan jalan baru, ditambah dengan rekayasa dan manajemen lalulintas terutama pengaturan efisiensi transportasi angkutan umum dan penambahan armadanya. Tetapi berapapun besarnya biaya yang dikeluarkan, kemacetan dan tundaan tetap tidak bisa dihindari. Ini disebabkan karena kebutuhan transportasi terus berkembang dengan pesat, sedangkan penyediaan fasilitas dan prasarana transportasi berkembang sangat lambat sehingga tidak bisa mengikutnya.

Langkah pemerintah dalam pemecahan masalah transportasi di Kota Pekanbaru telah banyak dilaksanakan, seperti adanya perluasan jalan, penyediaan angkutan massal, penyediaan fly over, penyediaan jembatan penyebrangan orang, perbaikan hingga pengaspalan permukaan jalan yang rusak, pengoptimalan daerah milik jalan, dan sebagainnya. Namun upaya ini belum cukup memecahkan permasalahan kemacetan lalulintas di Kota Pekanbaru, salah satunya adalah kemacetan di Jalan Riau. Jalan Riau tergolong jalan arteri sekunder dengan aktivitas guna lahan di kiri-kanan berupa perdagangan dan jasa, aktivitas jalan ini termasuk jalan yang padat mobilitasnya serta rentan terjadi tundaan atau kemacetan lalu lintas. Usaha yang dilakukan oleh pemerintah kota telah ada, berupa penyediaan angkutan massal hingga pemindahan pedagang kaki lima ke lokasi khusus, namun persoalan kemacetan masih tetap terjadi.

Pertumbuhan kendaraan di Kota Pekanbaru saat ini sangat tinggi. Merujuk data Dinas Perhubungan, Komunikasi dan Informasi Kota Pekanbaru, serta data Badan Pusat Statistik Kota Pekanbaru. Diketahui banyaknya Surat Izin Mengemudi (SIM) yang dikeluarkan dan jumlah kendaraan bermotor dalam kurun waktu 5 tahun terkahir (tahun 2008-2012) mengalami peningkatan dan penurunan yang signifikan. Melihat dan mencermati kondisi pada wilayah penelitian. Permasalahan transportasi perkotaan yang terjadi di sepanjang ruas Jalan Riau diantaranya sebagai berikut:

1. Guna lahan; Guna lahan di lokasi penelitian berupa guna lahan campuran, seperti guna lahan perdagangan dan jasa, permukiman, perkantoran, dan fasilitas umum lainnya dengan peruntukan di dominasi guna lahan perdagangan dan jasa. 
2. Kegiatan samping; Hambatan samping adalah dampak pada perilaku lalu lintas yang diakibatkan oleh aktivitas disisi jalan seperti pejalan kaki yang menyeberang jalan, angkot yang berhenti, perpakiran pada badan jalan dan keluar masuk kendaraan (Manual Kapasitas Jalan Indonesia (MKJI), 1997).

3. Tingkah laku pengguna jalan; Tingkah laku pengguna jalan yang dimaksud yaitu perilaku pengguna jalan yang tidak tertib terhadap peraturan lalu lintas.

4. Minimnya perangkutan umum; Minimnya perangkutan umum di lokasi penelitian menyebabkan masyarakat yang melintasi lokasi penelitian beralih menggunakan perangkutan pribadi, sehingga hal ini menigkatkan volume kendaraan pribadi. Kendaraan umum yang melintasi lokasi penelitian hanya ada angkot (oplet), taksi dan bus Trans Metro Pekanbaru.

5. Pertumbuhan perangkutan pribadi; Jumlah kepemilikan kendaraan bermotor meningkat tajam, seiring dengan pertumbuhan perekonomian dan selaras dengan kebutuhan manusia untuk melakukan suatu pergerakan dengan perangkat transportasi. Hal ini dapat dilihat dari data yang dimiliki oleh Dinas Pendapatan Daerah Kota Pekanbaru, pada tahun 2010, jumlah kendaraan berjumlah 453.672 unit dan meningkat pada tahun 2011 menjadi 474.596 unit.

6. Fisik ruas jalan; Adapun maksud dari fisik ruas jalan adalah kondisi ruas jalan yang tidak baik sehingga mengakibatkan penurunan kecepatan kendaraan saat melintas pada jalur tersebut seperti: jalan berlubang dan jalan yang tidak datar.

7. Sistem perpakiran; Sistem parkir di lokasi penelitian sangat memprihatinkan, dikarenakan banyak bangunan memiliki sarana parkir yang tidak memadai. Sehingga banyak kendaraan yang parkir tidak pada tempatnya seperti parkir berlapis dan parkir pada badan jalan. Kalaupun tempat parkir tersedia, tempat parkir tersebut tidak mampu menampung banyak kendaraan. Parkir di badan jalan inilah yang menyebabkan macet.

\section{KAJIAN PUSTAKA}

Studi lalu lintas yang terjadi dibeberapa ruas jalan Kota Pekanbaru sebagai bahan studi dan pertimbangan:

1. Berdasarkan hasil penelitian Wenni Trianingsih (2013), tentang Pengaruh Kawasan Pendidikan Formal Terhadap Kinerja Ruas Jalan Kaharudin Nasution Kota Pekanbaru; diperoleh hasil analisa yakni kinerja jalan dilokasi penelitian belum melampaui nilai derajat kejenuhan, sedangkan tingkat pelayanan 
berkategori D (mendekati tidak stabil dengan kecepatan yang masih bisa dipertahankan walaupun kadangkadang terhambat oleh kepadatan lalu lintas). Selain itu keberadaan kawasan pendidikan formal sangat mempengaruhi kinerja jalan tersebut dikarenakan peningkatan volume lalu lintas terjadi pada jam-jam puncak. Hal ini makin diperparah dengan rendahnya kedispilinan pengguna jalan dikarenakan mayoritas pengguna jalan adalah mahasiswa dan siswa, rendahnya disiplin pengguna jalan dibuktikan dengan banyaknya kendaraan yang melawan arah (porboden), hal ini terjadi karena kecenderungan pengguna jalan menggunakan kendaraan pribadi di banding kendaraan umum.

2. Berdasarkan hasil penelitian Lucky Prawira (2014), tentang Identifikasi Faktor-Faktor Penyebab Kemacetan Lalu Lintas Kota Pekanbaru, Studi Kasus Ruas Jalan Tuanku Tambusai; diperoleh hasil analisa yakni pertama; faktor penyebab kemacetan lalu lintas ruas jalan Tuanku Tambusai disebabkan oleh kapasitas jalan yang hanya mampu menampung 1.978,40 smp/jam, sedangkan volume kendaraan yang melintas berjumlah 4.340,2 smp/jam, dengan tidak sebandingnya kapasitas dan volume lalu lintas maka tingkat pelayanan jalan berkategori $\mathrm{F}$ (telah melewati batas puncak dari kapasitas jalan). Kedua; tarikan dan bangkitan pergerakan lalu lintas, dari hasil tarikan dan bangkitan dengan menggunakan regresi linier sederhana diperoleh simpulan bahwa jumlah pergerakan tarikan dan bangkitan perjalanan dipengaruhi oleh makin tingginya luas penggunaan lahan, yakni dengan persentase 97,5 persen.

Sebagian besar dari individu menyadari bahwa dunia yang sebagaimana dilihat tidak selalu sama dengan kenyataan, jadi berbeda dengan pendekatan sempit, tidak hanya sekedar melihat sesuatu tapi lebih pada pengertiannya terhadap sesuatu tersebut. Leavitt (Rosyadi, 2001) membedakan persepsi menjadi dua pandangan, yaitu pandangan secara sempit dan luas. Pandangan yang sempit mengartikan persepsi sebagai penglihatan, bagaimana seseorang melihat sesuatu. Sedangkan pandangan yang luas mengartikannya sebagai bagaimana seseorang memandang atau mengartikan sesuatu.

\section{METODE PENELITIAN}

Penelitian ini bertujuan untuk menemukenali persepsi atau pendapat masyarakat tentang alternatif pemecahan masalah transportasi perkotaan di Kota Pekanbaru, dengan lokasi penelitian di Jalan Riau. Batasan penelitian adalah:

1. Lokasi penelitan ini adalah Jalan Riau, Kota Pekanbaru dengan panjang jalan 2,5 Km. Dipilih karena lokasi penelitian ini merupakan jalan dengan 
mobilitas yang cukup tinggi serta banyak terjadi tundaan (kemacetan lalulintas).

2. Objek penelitian dilakukan pada transportasi darat yang melintasi Jalan Riau, berupa kendaraan pribadi maupun kendaraan umum, baik kendaraan roda dua, kendaraan ringan hingga kendaraan berat.

3. Subjek penelitian dilakukan pada masyarakat sebagai pengguna jalan dan masyarakat yang berada/menetap di sekitar lokasi penelitian. Dalam hal ini masyarakat yang menetap disekitar lokasi hanya pada pemilik bangunan di sekitar jalan saja.

Ruang lingkup wilayah penelitian adalah Jalan Riau, Kota Pekanbaru. Dipilih karena lokasi penelitian ini merupakan jalan dengan mobilitas yang cukup tinggi serta banyak terjadi tundaan (kemacetan lalu lintas). Untuk mencapai keluaran akhir dengan rumusan, tujuan dan sasaran yang ingin dicapai maka secara keseluruhan lingkup studi yang dibahas sebatas menemukenali persepsi masyarakat tentang alternatif pemecahan masalah transportasi perkotaan di Kota Pekanbaru, dengan studi kasus di Jalan Riau.

Penelitian ini tergolong pada penelitian deskriptif kuantitatif. Waktu penelitian selama tujuh hari yakni dimulai dari hari senin hingga hari minggu pada bulan Juni 2013. Agar informasi data yang diperoleh lebih lengkap, waktu pelaksanaan dilapangan terbagi dari tiga waktu yakni pagi hari pukul 07.00 Wib, siang hari pukul $12.00 \mathrm{Wib}$ dan petang atau sore hari pukul $17.00 \mathrm{Wib}$. Teknik untuk pengambilan sampel digunakan teknik accidental sampling (metode pengambilan sampel dengan memilih siapa yang kebetulan ada atau dijumpai) dengan cara simple random sampling (acak sederhana). Teknik penelitian ini digunakan pada ke dua sasaran yakni masyarakat sebagai pengguna jalan dan masyarakat sebagai pemilik lahan atau bangunan yang berada di kiri-kanan jalan di lokasi penelitian.

\section{HASIL DAN PEMBAHASAN}

Kondisi lalu lintas Jalan Riau pada sisi kiri dan kanan jalan umumnya dipenuhi oleh kawasan perdagangan dan jasa, yang meliputi pertokoan, apotik/balai pengobatan, showroom, penginapan, mall, peribadatan dan fasilitas lainnya. Kawasan inilah yang menyebabkan adanya daya tarik bagi setiap orang datang pada tiap bangunan yang ada, bukan hanya itu namun jalan ini memiliki akses penghubung ke wilayah seberang sungai siak yakni ke kecamatan rumbai dan rumbai pesisir serta akses penghubung ke luar kota. Sehingga arus kendaraan dari luar kota ataupun pinggiran kota menuju pusat kota akan melintasi Jalan Riau. Sehingga tidak jarang pada jam-jam tertentu terjadi kemacetan di Jalan Riau ini. Jam padat (peak hours) di Jalan Riau, relatif sering terjadi dan biasanya jam palin padat terjadi yakni dengan rentang waktu sebagai berikut; pagi pukul 06.30-07.30 Wib; siang pukul 12.30-13.30 
Wib; dan sore pukul 17.30-18.30 Wib. Pada jam padat tersebut umumnya aktifitas yang terjadi meliputi pergerakan masyarakat menuju perkantoran, menuju sekolah, menuju lokasi-lokasi perdagangan, menuju area makan (restoran), dan sebagainya.

Jalan Riau juga menjadi penghubung bagi masyarakat untuk menuju kawasan atau daerah di seberang sungai siak, yang melintasi jembatan Leigthon yang berada di Jalan Yos Sudarso. Kendaraan bermotor yang menuju kawasan seberang sungai siak cukup besar sehingga pemerintah kota memasang traffic light (rambu lampu merah) untuk mengurangi dan mengatur kendaraan yang memasuki Jalan Yos Sudarso. Namun kenyataan dilapangan, dengan adanya traffic light masalah baru timbul yaitu antrian panjang kendaraan.

\section{Klasifikasi Jalan dan Guna Lahan}

Jalan Riau termasuk dalam jalan perkotaan dengan fungsi jalan berupa arteri sekunder. Panjang jalan riau 1,6 kilometer dengan lebar jalan 8 meter, terdiri dari satu lajur dan terbagi menjadi dua arah pergerakan kendaraan, dan tanpa dibatasi oleh median jalan. Klasifikasi ini mengacu pada peraturan pemerintah pasal 17 Nomor 34 Tahun 2006. Namun kenyataan dilapangan tidak sesuai dengan acuan peraturan pemerintah tersebut. Jalan Riau merupakan salah satu jalan utama di Kota Pekanbaru memiliki pola berbentuk tulang daun. Jalan utama berfungsi sebagai batang dan sebagai cabangnya adalah jalanjalan lingkungan yang berada dikiri dan kanan Jalan Riau. Garis sempadan bangunan di sepanjang Jalan Riau sebesar 30 meter.

$$
\text { Berikut perbandingan peraturan }
$$
pemerintah mengenai fungsi jalan arteri sekunder dengan kondisi lapangan di Jalan Riau:

Tabel 1. Perbandingan Peraturan Pemerintah Pasal 17 Nomor 34 Tahun 2006 dengan Kondisi Jalan Riau

\begin{tabular}{|c|c|}
\hline $\begin{array}{c}\text { Peraturan Pemerintah } \\
\text { Pasal } 17 \text { Nomor } 34 \\
\text { Tahun } 2006\end{array}$ & $\begin{array}{c}\text { Kondisi Lapangan Jalan } \\
\text { Riau }\end{array}$ \\
\hline $\begin{array}{l}\text { Jalan arteri sekunder } \\
\text { didesain berdasarkan } \\
\text { kecepatan paling rendah } \\
30 \text { kilometer per jam, } \\
\text { dengan lebar paling } \\
\text { sedikit } 11 \text { meter. }\end{array}$ & $\begin{array}{l}\text { Kecepatan kendaraan } \\
\text { terendah pada jam } \\
\text { puncak kurang dari } 30 \\
\text { Km/jam, lebar jalan } 8 \\
\text { meter. }\end{array}$ \\
\hline $\begin{array}{l}\text { Jalan arteri sekunder } \\
\text { mempunyai kapasitas } \\
\text { yang lebih besar dari } \\
\text { pada volume lalu lintas } \\
\text { rata-rata. }\end{array}$ & $\begin{array}{l}\text { Kapasitas jalan lebih } \\
\text { kecil dari pada volume } \\
\text { lalu lintas yang } \\
\text { melintasi Jalan Riau. }\end{array}$ \\
\hline $\begin{array}{l}\text { Lalu lintas jalan arteri } \\
\text { sekunder tidak boleh } \\
\text { terganggu oleh lalu } \\
\text { lintas lambat. }\end{array}$ & $\begin{array}{ll}\text { Pada jam puncak, } & \text { arus } \\
\text { kendaraan } & \text { yang } \\
\text { melintasi Jalan } & \text { Riau } \\
\text { kerap terganggu. } & \end{array}$ \\
\hline $\begin{array}{lr}\text { Persimpangan } & \text { sebidang } \\
\text { pada jalan } & \text { arteri } \\
\text { sekunder } & \text { dengan } \\
\text { pengaturan } & \text { tertentu } \\
\text { harus dapat memenuhi } \\
\text { ketentuan sebagaimana } \\
\text { dimaksud pada ayat (1) } \\
\text { dan (2). }\end{array}$ & $\begin{array}{lr}\text { Fakta/kondisi } & \text { di } \\
\text { lapangan tidak sesuai } \\
\text { dengan } \quad \text { Peraturan } \\
\text { Pemerintah Pasal } 17 \\
\text { Nomor 34 Tahun 2006. }\end{array}$ \\
\hline
\end{tabular}

Sumber: Hasil Analisa, 2014

Kondisi Jalan Riau 95\% dalam kondisi baik, sedangkan 5\% dalam kondisi kurang baik (aspal dalam kondisi rusak), kondisi telah teraspal hotmix. Jalan Riau, Kota Pekanbaru termasuk dalam klasifikasi jalan perkotaan dan fungsi jalan berupa arteri sekunder. Jalan Riau memiliki panjang jalan yakni sepanjang 2,5 Km. Dengan lebar 8 meter. Jalan Riau terdiri dari satu lajur dan terbagi dua arah pergerakan tanpa dibatasi oleh median jalan. Jalan Riau merupakan 
salah satu jalan utama di Kota Pekanbaru memiliki pola tulang daun. Jalan arteri sekunder berfungsi sebagai tulangnya dan cabangnya adalah jalan-jalan lingkungan yang berada di sisi kanan-kiri koridor Jalan Riau.

Penggunaan lahan di sekitaran kiri dan kanan Jalan Riau diperuntukkan bagi lahan perdagangan dan jasa, yang meliputi pertokoan, penginapan, rumah makan, café, showroom, mall, peribadatan, apotik/balai pengobatan dan fasilitas umum lainnya. Pola penggunaan lahan di sepanjang Jalan Riau di pengaruhi oleh pola jaringan jalan, yaitu jalan arteri sekunder yang diikuti oleh perkembangan aktivitas di sepanjang jalan tersebut.

Hambatan samping adalah dampak pada kinerja lalu lintas yang diakibatkan oleh aktivitas di sisi jalan seperti pejalan kaki yang menyeberang jalan, angkutan kota (angkot) yang berhenti, keluar masuk kendaraan, dan kendaraan lambat (MKJI, 1997). Hambatan samping pada Jalan Riau terdiri dari parkir yang tidak pada tempatnya atau parkir pada badan jalan, adanya aktifitas keluar masuk arus lalu lintas pada jalan-jalan lingkungan, adanya aktifitas keluar masuk kendaraan pada area pertokoan, bank, mall, dan lainnya, adanya aktifitas penyeberangan orang, perilaku pengguna kendaraan bermotor yang tidak mengindahkan peraturan lalu lintas, dan sebagainya. Adanya aktivitas/kegiatan parkir dibahu jalan maupun di atas trotoar menyebabkan terjadinya tundaan/kemacetan disaat kendaraan sedang padat. Selain itu kesemrawutan kendaraan disaat parkir di areal yang bukan peruntukannya menyebabkan tatanan kota tidak bagus secara visual.

Kegiatan penyebrangan orang yang tidak pada tempatnya menimbulkan tundaan bagi kendaraan dan menimbulkan rasa ketidaknyamanan bagi penyebrang. Adanya kegiatan penyebrangan orang menandakan sangat perlu jembatan penyebrangan, di sepanjang lokasi penelitian ini tidak ada jembatan penyebrangan orang. Selain adanya kegiatan penyebrangan orang, dilokasi penelitian juga memiliki jalan-jalan lingkungan yang menghubungkan daerah permukiman penduduk dengan lokasi penelitian. Kegiatan keluar dan masuknya kendaraan bermotor dari dan ke jalan lingkungan menyebabkan terjadinya tundaan kendaraan sehingga terkadang menyebabkan kemacetan lalu lintas.

Selain kendaraan pribadi, untuk memudahkan pergerakan masyarakat dilokasi penelitian, pemerintah kota Pekanbaru mengijinkan pengoperasian beberapa jenis perangkutan umum yakni diantaranya angkutan umum kota (oplet, dan taksi) dan angkutan umum massal berupa Bus Trans Metro Pekanbaru. Bus ini berkategori kecil, memiliki kapasitas muatan penumpang sebanyak 22 orang serta memiliki pendingin udara yang menyejukkan bagi masyarakat Kota Pekanbaru, dikarenakan suhu Kota Pekanbaru yang relatif panas. Bus ini beroperasi mulai dari pukul 06.00 WIB hingga pukul $21.00 \mathrm{WIB}$. 
Selain masalah waktu tunggu yang lama, jumlah sarana yang masih sedikit dan sedikitnya jumlah kapasitas angkut penumpang, bus ini memiliki kendala lain yakni prasarana berupa halte yang memiliki jarak untuk saat ini cukup jauh antara halte, sehingga masyarakat yang memiliki keperluan dengan jarak jangkau dekat dan daerah tujuan yang tidak tersedia halte lebih memilih menggunakan sarana angkutan umum lain hingga bahkan lebih memilih menggunakan angkutan pribadi. Kondisi halte bus Trans Metro Pekanbaru di lokasi penelitian umumnya tidak terawat hal ini dapat dilihat dari foto dokumentasi diatas; kondisi halte dilokasi penelitian telah berubah fungsi menjadi tempat tinggal bagi sebagian gelandangan, orang gila hingga tuna wisma, selain itu kondisi halte juga berbau tidak sedap sehingga sedikit masyarakat yang mau masuk ke halte ini. Selain halte, baru-baru ini pemerintah Kota Pekanbaru membuat semi halte baru agar selain dapat menaik dan menurunkan penumpang bagi angkutan bus trans metro juga dapat digunakan sebagai halte peruntukan sarana perangkutan kota lainnya.

Kegiatan perangkutan umum berupa oplet yang sering menurunkan dan menaikkan penumpang tidak pada tempatnya atau sembarangan menambah kesemrawutan jalan di lokasi penelitian, selain oplet juga ada kegiatan perangkutan umum berupa taksi yang juga kerap parkir di atas trotoar hingga ke badan jalan sehingga kegiatan ini makin memperburuk tatanan kota secara visual dan makin memperburuk kondisi lalu lintas di lokasi penelitian.

\section{Kinerja Jalan}

1. Analisa Kapasitas Jalan Riau

Analisa kapasitas jalan adalah analisa untuk mengetahui banyaknya kendaraan yang dapat melintasi jalan suatu jalan persatuan mobil penumpang perjam (smp/jam). Kapasitas jalan ditentukan oleh faktor-faktor berikut:

Tabel 2. Faktor-Faktor Kapasitas Jalan Perkotaan

\begin{tabular}{|c|c|c|}
\hline $\begin{array}{l}\text { Faktor-faktor } \\
\text { Kapasitas Jalan } \\
\text { (MKJI, 1997) }\end{array}$ & Kondisi & $\begin{array}{c}\text { Nilai } \\
\text { Faktor } \\
\text { Kapasitas } \\
\text { Jalan } \\
\end{array}$ \\
\hline $\begin{array}{c}\text { Kapasitas } \\
\text { dasar (smp/jam) }\end{array}$ & $2 / 2 \mathrm{UD}$ & 2.900 \\
\hline \begin{tabular}{l}
\multicolumn{1}{c}{ Faktor } \\
penyesuaian \\
lebar jalan lalu \\
lintas
\end{tabular} & 8 meter & 1,14 \\
\hline \begin{tabular}{l}
\multicolumn{1}{c}{ Faktor } \\
penyesuaian \\
akibat pemisah \\
arah
\end{tabular} & $\begin{array}{l}\text { Jalan dua } \\
\text { arah }\end{array}$ & 1 \\
\hline \begin{tabular}{l}
\multicolumn{1}{c}{ Faktor } \\
penyesuaian \\
hambatan \\
samping dan \\
lebar bahu jalan
\end{tabular} & $\begin{array}{l}\text { Gangguan } \\
\text { samping } \\
\text { tinggi dan } \\
\text { lebar bahu } \\
\text { jalan } 1 \mathrm{~m}\end{array}$ & 0,86 \\
\hline $\begin{array}{l}\text { Faktor } \\
\text { penyesuaian } \\
\text { ukuran kota }\end{array}$ & $\begin{array}{l}\text { Mendekati } 1 \\
\text { juta jiwa }\end{array}$ & 0,94 \\
\hline
\end{tabular}

Sumber: Hasil Analisa, 2014

$$
\begin{aligned}
& \mathrm{C}=\mathrm{Co} \times \mathrm{FCw} \times \mathrm{FCsp} \times \mathrm{FCsf} \times \mathrm{FCcs} \\
& \mathrm{C}=2900 \times 1,14 \times 1 \times 0,86 \times 0,94 \\
& \mathrm{C}=2672,6 \mathrm{smp} / \mathrm{jam}
\end{aligned}
$$

Kapasitas Jalan Riau per jam dapat menampung kendaraan sebesar 2672,6 satuan mobil penumpang per jam (smp/jam).

\section{Analisa Tingkat Pelayanan Jalan}

Analisa tingkat pelayanan jalan menggambarkan nilai kejenuhan, serta padat atau tidaknya suatu jalan berdasarkan 
perbandingan volume arus kendaraan per satuan waktu dengan kapasitas jalan per satuan waktu (MKJI, 1997).

Tabel 3. Tingkat Pelayanan Jalan Riau

\begin{tabular}{|c|l|c|c|c|}
\hline $\begin{array}{c}\text { Arah } \\
\text { Arus }\end{array}$ & Waktu & $\begin{array}{c}\text { Vol } \\
\text { Lalin } \\
\text { smp/jam }\end{array}$ & $\begin{array}{c}\text { Nilai } \\
\text { LOS }\end{array}$ & $\begin{array}{c}\text { Kategori } \\
\text { LOS }\end{array}$ \\
\hline $\begin{array}{c}\text { Timur } \\
\text { ke } \\
\text { Barat }\end{array}$ & Pagi & 2.879 & 1,07 & F \\
\cline { 2 - 5 } & Siang & 2.643 & 0,98 & E \\
\cline { 2 - 5 } $\begin{array}{c}\text { Barat } \\
\text { ke } \\
\text { Timur }\end{array}$ & Pore & 4.436 & 1,65 & F \\
\cline { 2 - 5 } & Siang & 3.154 & 1,18 & F \\
\cline { 2 - 5 } & Sore & 5.167 & 1,93 & F \\
\hline
\end{tabular}

Sumber: Hasil Analisa, 2014

Kategori Los F, kondisi lalu lintas telah melewati batas puncak dari kapasitas Jalan Riau 2672,6 smp/jam. Kondisi sudah tidak mampu lagi menampung arus kendaraan, sehingga tundaan berat seperti kemacetan lalu lintas relatif terjadi.

3. Kondisi Perpakiran dan Pengaruhnya pada Kapasitas Jalan

Kondisi parkir pada badan jalan sangat mempengaruhi kapasitas jalan. Lebar jalan yang tersita oleh kegiatan perpakiran (termasuk lebar manuver) tentu mengurangi kemampuan jalan dalam menampung arus kendaraan yang lewat. Penurunan kapasitas jalan bukan saja disebabkan oleh pengurangan lebar jalan tetapi juga oleh proses kegiatan kendaraan yang masuk dan keluar dari petak parkir. Semakin lebar kendaraan maupun sudut kendaraan, semakin besar pula pengurangan kapasitas jalannya. Dari hasil pengamatan di Jalan Riau, umumnya sudut parkir kendaraan pada badan jalan berupa sudut $0^{\circ}$ atau sudut paralel. Pengurangan kapasitas jalan akibat adanya parkir akan terasa nyata pada jam padat kendaraan.

Analisa sederhana untuk menentukan pengaruh parkir di badan jalan dengan kapasitas jalan; lebar kendaraan kecil (sedan) umumnya 1,7 meter (berdasarkan Direktorat Jenderal Bina Sistem Lalu Lintas Angkutan Kota, Dirjen Perhubungan Darat tentang Pedoman Perenacanaan dan Pengoperasian Fasilitas Parkir, 1998) lebar lajur Jalan Riau 4 meter sehingga kapasitas jalan yang tersisa adalah 2,3 meter. Dengan adanya aktivitas parkir tersebut akan memperkecil kapasitas dan akan memperbesar masalah transportasi yang ada di lokasi tersebut. Disimpulkan bahwa, aktivitas perpakiran sangat mengurangi kapasitas ruas jalan dan penurunan kapasitas dapat meningkatkan terjadinya masalah transportasi perkotaan, salah satunya berupa tundaan arus lalu lintas (kemacetan).

\section{Identifikasi Persepsi Masyarakat Terkait Penyebab Masalah Transportasi di Jalan Riau Kota Pekanbaru dan Alternatif Pemecahannya}

Persepsi masyarakat tentang permasalahan transportasi perkotaan di Jalan Riau diantaranya; berupa kemacetan lalu lintas, ketidaktertiban berkendara, adanya parkir dibahu jalan serta permasalahan lainnya. Berdasarkan penyebaran kuesioner kepada pengguna jalan, diperoleh hasil bahwa masalah transportasi perkotaan di Jalan Riau adalah:

1. Kemacetan Lalu Lintas

Kemacetan lalu lintas yang terjadi di 
Jalan Riau menurut persepi pengguna jalan disebabkan oleh beragam masalah diantaranya:

a. Arus lalu lintas melebihi kapasitas jalan

Arus lalu lintas yang melintasi Jalan Riau cukup besar, jumlah arus lalu lintas terbesar berada pada waktu padat sore hari yakni sebanyak 5.167 satuan mobil penumpang per jam dan jumlah arus lalu lintas terkecil berada pada waktu padat siang sebanyak 2.643 satuan mobil penumpang per jam.

Kapasitas Jalan Riau dengan panjang $1,6 \mathrm{~km}$ dan lebar $8 \mathrm{~m}$, mampu menampung 2.672,6 satuan mobil penumpang per jam. Lebih besarnya jumlah arus kendaraan yang melintasi Jalan Riau dibandingkan kapasitas jalan yang ada menimbulkan kemacetan atau tundaan arus lalu lintas yang tidak terelakkan. Sebanyak 34 respponden membenarkan hal tersebut.

b. Pengaturan Traffic Light

Berdasarkan hasil wawancara dengan Kepala Bidang Perangkutan Dinas Perhubungan Kota Pekanbaru, dengan nama Sunarko, Atd, MT; pada hari Selasa tanggal 29 April 2014 di Kantor Dinas Perhubungan Kota Pekanbaru, pukul 10.00 Wib hingga pukul 12.00 Wib. Menyatakan Rentang waktu lampu lalu lintas yang cukup panjang diharapkan akan mampu menertibkan arus kendaraan, namun tidak menutup kemungkinan terjadinya antrian kendaraan yang cukup panjang.

Hal ini sesuai dengan persepsi pengguna jalan yang menyebutkan pengaturan traffic light dengan rentang waktu lama membuat antrian kendaraan cukup panjang sehingga mengganggu arus kendaraan lainnya. Persepsi pengguna jalan yang menyebutkan hal ini sebanyak 17 responden.

c. Ketidaktertiban pengguna jalan Pengamat transportasi perkotaan Hapriadi Malik, SSi, MT; pada hari Selasa tanggal 29 April 2014, pukul 15.00 Wib di Kantor Bidang Kepegawaian Daerah Provinsi Riau. Ketidaktertiban pengguna jalan dikarenakan arus lalu lintas Jalan Riau terlalu padat sehingga menimbulkan ketidaksabaran pengguna jalan dalam berlalu lintas yang menyebabkan ketidakteraturan tersebut.

Berdasarkan hasil wawancara disimpulkan bahwa persepsi pengguna jalan dengan pernyataan ketidaktertiban pengguna jalan adalah benar adanya, pengguna jalan yang berppendapat untuk hal ini adalah sebanyak 22 responden.

2. Sistem Perpakiran

Masalah sistem perpakiran yang terjadi 
di Jalan Riau menurut persepsi para ahli transportasi disebabkan oleh beragam masalah diantaranya sebagai berikut:

a. Terbatasnya lahan parkir

Terbatasnya lahan parkir di Jalan Riau disebabkan karena besarnya tarikan pergerakan kendaraan pada masingmasing guna lahan, guna lahan Jalan Riau memiliki fungsi sebagai perdagangan dan jasa. Volume kendaraan yang bertambah tiap tahun, luas lahan parkir terbatas dan tidak adanya perluasan atau pembangunan lahan parkir baru sehingga menyebabkan lahan parkir yang ada tidak mampu menampung kendaraan yang parkir di areal tersebut. Tarikan kendaraan pada tiap guna lahan di Jalan Riau tergolong besar sehingga perlu dikaji ulang sistem perpakiran yang ada sehingga tidak ada parkir dalam kondisi on street.

b. Petugas parkir tidak resmi

Petugas parkir tidak resmi yang beroperasi di Jalan Riau sangat berhubungan erat dengan kondisi perpakiran yang terbatas. Petugas parkir tidak resmi ini menjadi parasit bagi pengguna jalan dan Pemerintah Kota, karena kota akan terlihat tidak tertata secara visual sedangkan bagi pengguna jalan, dengan memakirkan kendaraan di badan jalan atau tempattempat yang tidak seharusnya akan merugikan pengguna kendaraan itu sendiri salah satunya saat terjadi razia.
Tabel 4. Alternatif Pemecahan Masalah Transportasi di Jalan Riau Kota Pekanbaru

\begin{tabular}{|c|c|c|}
\hline Komponen & $\begin{array}{c}\text { Masalah } \\
\text { Transportasi } \\
\text { Perkotaan } \\
\text { di Jalan Riau } \\
\end{array}$ & $\begin{array}{l}\text { Alternatif } \\
\text { Pemecahan } \\
\text { Masalah }\end{array}$ \\
\hline $\begin{array}{l}\text { Kemacetan } \\
\text { lalu lintas }\end{array}$ & \begin{tabular}{|l} 
a. \\
Arus lalu lintas \\
melebihi \\
kapasitas jalan \\
b. Pengaturan \\
Traffic Light \\
c. Ketidaktertiban \\
pengguna jalan
\end{tabular} & $\begin{array}{ll}\text { a. } & \text { Pelebaran } \\
\text { jalan } \\
\text { b. Arus } \\
\text { kendaraan } \\
\text { satu arah } \\
\text { c. Optimalisasi } \\
\text { sarana dan } \\
\text { prasarana } \\
\text { angkutan } \\
\text { umum } \\
\text { massal }\end{array}$ \\
\hline $\begin{array}{l}\text { Sistem } \\
\text { perpakiran }\end{array}$ & $\begin{array}{l}\text { a. Terbatasnya } \\
\text { lahan parkir } \\
\text { b. Petugas parkir } \\
\text { tidak resmi }\end{array}$ & $\begin{array}{l}\text { Penyediaan } \\
\text { gedung parkir. }\end{array}$ \\
\hline
\end{tabular}

Sumber: Hasil Analisa, 2014

\section{KESIMPULAN DAN SARAN}

\section{Kesimpulan}

Masalah transportasi perkotaan di Jalan Riau berupa kemacetan lalu lintas dan sistem perpakiran yang buruk, kemacetan lalu lintas dikarenakan tidak sebandingnya volume kendaraan yang melintasi Jalan Riau dibandingkan kapasitas jalan tersebut.

1. Arus lalu lintas yang melintasi Jalan Riau telah melebihi kapasitas jalan sehingga menimbulkan kemacetan hingga ketidaktertiban pengguna jalan.

2. Terbatasnya lahan parkir menyebabkan pengguna jalan memanfaatkan badan jalan sebagai lahan parkir yang mengganggu ketertiban umum dan menimbulkan kesemrawutan secara visual.

\section{Saran}

Solusi yang memungkinkan adalah perlunya kajian yang lebih baik dari 
Pemerintah Kota Pekanbaru sehingga masalah kemacetan dapat terselesaikan.

\section{DAFTAR PUSTAKA}

Adisasmita, Sakti Adji. 2009. Perencanaan Pembangunan Transportasi, Pusat Pengembangan Keuangan dan Ekonomi Daerah. Makassar ; Fakultas Ekonomi, Universitas Hasanuddin.

Adler, Hans A. 1983. Evaluasi Ekonomi Proyek-proyek Pengangkutan. (terjemahan Paul Sitohang). Jakarta ; Penerbit Universitas Indonesia.

Budi D. Sinulingga. 1999. Pembangunan Kota Tinjauan Regional dan Lokal. Jakarta : Penerbit Pustaka Sinar Harapan.

Conyers, Diana and Hills, Peter. 1984. An Introduction To Development Planning The Third World. Scotland : John Wiley and Sons Ltd.

Direktorat Jenderal Bina Marga. (1997).

Manual Kapasitas Jalan Indonesia (MKJI). Jakarta.

Miro, Fidel. 2005. Perencanaan Transportasi Untuk Mahasiswa, Perencana dan Praktisi. Jakarta : Penerbit Erlangga.

Morlok, Edward K. 1998. Pengantar Teknik dan Perencanaan Transportasi (terjemahan Johan $K$ Hainim). Jakarta : Penerbit Erlangga.
Nazir, Moh. 2009. Metode Penelitian. Jakarta : Ghalia Indonesia.

Saraswati, Vebrina. 2007. Pengaruh Kegiatan-Kegiatan di Sepanjang Koridor terhadap Kinerja Jaringan Jalan Mayjend Sungkono. Tugas Akhir. Surabaya : Program Studi Perencanaan Wilayah dan Kota Institut Teknologi Sepuluh November.

Sijabat, Jesno. 2007. Kajian Dampak Perubahan Jenis Penggunaan Lahan Terhadap Kinerja Ruas Jalan Studi Kasus: Koridor Jalan Arteri Cicaheum - Cibiru. Skripsi. Bandung : Perencanaan Wilayah dan Kota ITB.

Sujarto, Djoko. 1985. Beberapa Pengertian Tentang Perencanaan Fisik. Jakarta : Penerbit LP3ES.

Tamin, O.Z. (2000). Perencanaan dan Permodelan Transportasi. Bandung : Penerbit ITB.

Wahyuni, R. (2008). Pengaruh Parkir Pada Badan Jalan Terhadap Kinerja Ruas Jalan. Tugas Akhir. Medan : Jurusan Teknik Sipil Universitas Sumatera Utara.

Warpani, Suwardjoko. Merencanakan Sistem Pengangkutan. Bandung : Penerbit ITB.

Yunus, Hadi Sabari. (2000). Struktur Tata Ruang Kota. Yogyakarta : Pustaka Pelajar. 